\title{
Aantrekkelijker maken van het vak: de discussie gaat verder
}

\author{
Onlangs verscheen een plan voor het - zo nodig - snel kunnen \\ opschalen van de ic-capaciteit. Daarvoor zijn meer ic-verpleegkun- \\ digen nodig, maar ook voor andere verpleegkundigen moet het vak \\ aantrekkelijker worden.
}

tekst Jeroen Wapenaar

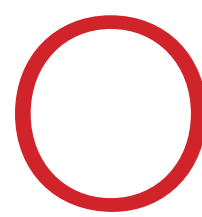
p 30 juni kreeg minister van Medische Zorg Martin van Rijn ${ }^{3}$ het Opschalingsplan COVID-19 aange-

boden. Dit plan van het Landelijk Netwerk Acute Zorg (LNAZ) moet het mogelijk maken de zorg voor covid-patiënten op te vangen zonder dat het ten koste gaat van de reguliere non-covidzorg. Het LNAZ wil daarvoor maximaal inzetten op het aantrekken en behouden van (ic-)verpleegkundigen. Voorwaardes daarvoor zijn meer zeggenschap, waardering en loopbaanperspectief voor verpleegkundigen. Zo pleit men voor meer functies waarin verpleegkundigen patiëntenzorg kunnen combineren met een studie, het doen van onderzoek of meedenken over beleid.

Omdat de zorg voor covid-patiënten waarschijnlijk nog lang noodzakelijk is, moet de ic-capaciteit structureel uitgebreid worden naar 1350 bedden, schrijft het LNAZ. Ook moet voor een eventuele nieuwe piek opschaling naar 1700 icbedden mogelijk zijn. Daarom is ook een stappenplan opgenomen voor het opleiden van collega's die ic-verpleegkundigen kunnen ondersteunen. Zo zouden verpleegkundigen van bijvoorbeeld de ccu, high care en seh korte scholingsprogramma's aangeboden moeten krijgen.
Niet-gespecialiseerde verpleegkundigen die op covid-verpleegafdelingen kunnen werken, moeten tussen nu en 1 oktober gericht opgeleid worden voor het werken met een optiflow, tracheacanule en voor palliatieve zorg. Veel ziekenhuizen zijn hier volgens de LNAZ al mee begonnen.

\section{Zeggenschap}

De V\&VN-IC en de Nederlandse Vereniging voor Intensive Care (NVIC) leverden input voor het opschalingsplan. Zij wijzen in hun advies bijvoorbeeld op het belang van een positieve werkomgeving voor iedere verpleegkundige. ${ }^{1}$ Suggesties zijn een standaard powernap tijdens de nachtdiensten en gezonde voeding in de nacht op het juiste tijdstip, wat sommige ziekenhuizen al aanbieden. ${ }^{2}$

Deze concrete adviezen zijn niet in het opschalingsplan opgenomen, maar wel dat verpleegkundigen volwaardige gesprekspartners moeten zijn bij de besluitvorming in organisaties. Volgens de voorzitter van V\&VN-IC Rowan Marijnissen vergt dit ook iets van verpleegkundigen zelf. Op de website van V\&VN schrijft ze: ' Zeggenschap wordt je nooit in de schoot geworpen. Je moet er altijd zelf iets voor doen. Wacht daarom niet af en stap met dit plan in de hand op je bestuur af. Ga het gesprek aan. Wat is bij ons mogelijk?'

\section{Advies Bianca Buurman}

Zeggenschap, waardering en loopbaanperspectief hebben ook voor Chief Nursing Officer Bianca Buurman prioriteit. Naar verwachting presenteert zij eind augustus haar advies over de positionering van verpleegkundigen, waarin deze 3 thema's zeker aan bod komen. Ze schreef in mei al dat er te weinig verpleegkundigen en verzorgenden werken om naast coronazorg ook volledige reguliere zorg te kunnen verlenen. 'Om de uitstroom te verkleinen moet er echt meer aandacht komen voor verminderen van de werkdruk, zorgen voor uitdaging in het werk, meer tijd voor de patiënten en cliënten, goede loopbaanpaden, zeggenschap en salaris.' Ze pleitte verder voor voldoende hersteltijd voor verpleegkundigen en verzorgenden na de afgelopen maanden, om een toename van uitval door ziekte of uitstroom te voorkomen. ${ }^{4}$

\section{Noten:}

1 Advies Uitbreiding ic-capaciteit, 23 juni aangeboden aan LNAZ, zie nieuwsbericht op www.venvn.nl.

2 Nursing schreef diverse artikelen over nachtdiensten draaien en de impact ervan, zoek op www.nursing.nl op slaapproblemen.

3 Het Opschalingsplan COVID-19 staat op www.Inaz.nl.

4 www.nursing.nl/te-weinig-verpleegkundigen-voor-reguliere-en-coronazorg-naastelkaar/ 